\title{
PERUBAHAN TEKSTUR KERUPUK UDANG MENGGUNAKAN PASIR KALI DAN PASIR GUNUNG SEBAGAI MEDIA PENGHANTAR PANAS PADA PROSES PENYANGRAIAN
}

\section{CHANGES IN THE TEXTURE OF SHRIMP CRACKERS USING KALI SAND AND MOUNTAIN SAND AS HEAT CONDUCTION MEDIA IN THE ROASTING PROCESS}

\author{
Sudirman Rachim ${ }^{1)}$, Jamaluddin P 2), Kadirman ${ }^{3)}$ \\ ${ }_{1}^{1}$ Alumni Program Studi Pendidikan Teknologi Pertanian \\ ${ }^{2}$ dan ${ }^{3}$ Dosen PTP FT UNM \\ immankblaugrana30@gmail.com
}

\begin{abstract}
ABSTRAK
Tekstur pada makanan terdiri atas halus dan kasar, cair dan padat, keras dan lembek. Tekstur sangat mempengaruhi citra atau rasa makanan yang dapat dirasakan dengan tekanan dan gerakan dari reseptor pada mulut. Salah satu jenis makanan yang bergantung pada tekstur ialah kerupuk.. Tujuan dari penelitian ini adalah untuk mengetahui perubahan tekstur kerupuk menggunakan pasir kali dan pasir gunung sebagai media penghantar panas pada proses penyangraian dengan menggunakan suhu yaitu $120^{\circ} \mathrm{C}, 140^{\circ} \mathrm{C}$ dan $160^{\circ} \mathrm{C}$ dan berbagai variasi waktu yaitu 10, 15, 20 dan 25 detik. Parameter yang diukur adalah nilai hardness kerupuk dan kadar air kerupuk. Hasil penelitian menunjukkan bahwa pasir kali dan pasir gunung dapat mengubah tekstur kerupuk melalui penyangraian hal tersebut dikarenakan adanya perpindahan panas dari dinding pemanas pada pasir sehingga mempengaruhi kadar air dan kadar pati dalam kerupuk yang disangrai, dalam proses penyangraian, suhu mempengaruhi tekstur kerupuk yang dihasilkan dimana suhu yang baik digunakan yaitu $140{ }^{\circ} \mathrm{C}$ untuk pasir kali dan $160^{\circ} \mathrm{C}$ untuk pasir gunung dengan masing-masing waktu 20 dan 25 detik.
\end{abstract}

Kata Kunci : Tekstur, Perubahan kadar air, Penyangraian, kerupuk

\section{ABSTRACT}

The texture of the food consists of smooth and rough, liquid and solid, hard and soft. Texture greatly affects the image or taste of food that can be felt with pressure and movement of receptors in the mouth. One of the types of food that depends on texture is crackers. The purpose of this study was to determine the changes in texture of crackers using sand kali and mountain sand as heat conductive media for roasting by using temperatures of $120^{\circ} \mathrm{C}, 140^{\circ} \mathrm{C}$ and $160^{\circ} \mathrm{C}$ and various variations of time ie 10,15, 20 and 25 seconds. The parameters measured are the value of cracker hardness and cracker water content. The results showed that river sand kali and mountain sand can change the texture of crackers through roasting, because of the heat transfer from the heating wall in the sand so that it affects the moisture content and starch content in roasted crackers, in the roasting process, the temperature affects the texture of the crackers produced where good temperature id use is $140{ }^{\circ} \mathrm{C}$ for kali sand times and $1600^{\circ} \mathrm{C}$ for mountain sand with a time of 20 and 25 seconds.

Keywords: Texture, Changes in water content, roasting, crackers 


\section{PENDAHULUAN}

Kerupuk merupakan makanan khas Indonesia dan sudah sangat dikenal oleh masyarakat. Kerupuk sangat beragam dalam bentuk, ukuran, warna, bau, rasa, ataupun teksturnya. Kerupuk bertekstur garing dan sering dijadikan pelengkap untuk berbagai makanan Indonesia seperti nasi goreng dan gado-gado.

Kerupuk terbuat dari adonan yang bahan utamanya adalah pati. Berbagai bahan berpati dapat diolah menjadi kerupuk, diantaranya adalah ubi kayu, ubi jalar, beras, sagu, terigu, tapioka dan talas. Pada umumnya pembuatan kerupuk adalah sebagai berikut, bahan berpati dilumatkan bersama atau tanpa bumbu, kemudian dimasak (direbus atau dikukus) dan dicetak berupa lempengan tipis lalu dijemur yang disebut kerupuk kering. Sebelum dikonsumsi, kerupuk kering digoreng terlebih dahulu baik itu dengan cara penyangraian ataupun penggorengan menggunakan minyak. Pada umumnya, sebelum dikonsumsi kerupuk terlebih dahulu digoreng menggunakan minyak sehingga untuk penyimpanan kerupuk pada suhu ruang akan menyebabkan terjadinya perubahan pada kerupuk yang diakibatkan penyesuaian terhadap kondisi lingkungan. Perubahan yang sangat nyata adalah ketengikan yang diakibatkan oleh proses oksidasi lemak (Nimana,dkk. 2017). Penggunaan minyak goreng juga sering menimbulkan permasalahan yaitu: (1) Ketersediaannya kurang seimbang dengan kebutuhan sehingga menyebabkan harga melambung cukup tinggi; (2) Konsumsi makanan yang mengandung lemak disinyalir akan berdampak kurang baik bagi kesehatan; (3) Penggunaan minyak untuk penggorengan digunakan secara berulang,
(Susanna, dkk 2017). Dalam penelitian ini proses pengolahan kerupuk akan dilakukan dengan cara penyangraian menggunakan pasir kali dan pasir gunung sebagai media penghantar panas untuk mengetahui tekstur kerupuk.

Ada beberapa keuntungan apabila penggorengan dilakukan tanpa menggunakan minyak (menggunakan pasir). Keuntungan tersebut antara lain produk tidak mengandung minyak goreng sehingga tidak mudah tengik, pasir sebagai media penghantar panas mudah di dapat dan murah, produk yang mengalami penurunan kerenyahan (melempem) mudah dilakukan rekondisi kerenyahannya dengan cara dijemur pada sinar matahari atau dipanaskan pada suhu yang tidak terlalu tinggi $\quad\left(35-45^{\circ} \mathrm{C}\right), \quad$ mengurangi ketergantungan penggorengan menggunakan minyak goreng (Siswantoro dkk., 2010).

Penyangraian adalah proses perpindahan panas baik tanpa media maupun menggunakan pasir dengan tujuan mendapatkan cita rasa tertentu. Seperti penyangraian kerupuk, kopi, biji kakao dan kacang. Pengolahan bahan pangan dengan cara penyangraian dapat dilakukan baik secara manual maupun menggunakan mesin. Proses penyangraian dengan menggunakan wajan yaitu terjadi perpindahan panas dari permukaan pemanas kedalam bahan. Penyangraian juga dapat dilakukan menggunakan mesin penyangrai. Penyangrai yang sering digunakan dalam industri masal saat ini adalah penyangrai menggunakan mesin. Penyangraian atau biasa juga dikenal sebagai penggorengan dengan media pasir yang menggantikan posisi minyak merupakan salah satu metode untuk 
menguapkan air dengan perpindahan panas dari media berupa pasir ke permukaan bahan yang disangrai yang mengakibatkan kadar air menguap dan menghasilkan kerupuk yang memiliki tekstur renyah. (Irmayanti, dkk. 2017).

\section{TUJUAN PENELITIAN}

Untuk mengetahui perubahan tekstur kerupuk makanan berpati menggunakan pasir kali dan pasir gunung sebagai media penghantar panas pada proses penyangraian.

\section{METODE PENELITIAN}

Penelitian ini penelitian eksperimen yang terdiri dari 2 faktor dan 3 kali ulangan. Faktor jenis pasir menggunakan pasir kali dan pasir gunung dengan faktor lama penyangraian dengan 4 taraf faktor $(10,15$, 20 dan 25) detik dan faktor suhu dengan 3taraf $\left(120,140\right.$ dan $\left.160^{\circ} \mathrm{C}\right)$. Dengan demikian banyaknya perlakuan yang akan dicobakan sebanyak 72 kombinasi perlakuan.

Desain penelitian yang dilakukan yaitu sebelum dan sesudah penyangraian dilakukan penggukuran tekstur kerupuk untuk mengetahui testur awal dan tekstur akhir dari kerupuk udang. Penyangraian dilakukan menggunakan media pasir sebagai penghantar panas menggunakan mesin penyangrai dengan sumber panas dari kompor gas. Penyangraian kerupuk menggunakan 2 jenis pasir yaitu pasir kali dan pasir gunungdengan waktu penyangraian 10,15,20 dan 25 detik.

Proses penyangraian dengan menggunakan mesin penyangrain yang diamati perubahan tekstur kerupuk berpati selama proses penyangraian sesuai dengan suhu dan waktu yang ditentukan.
Variabel penelitian adalah jenis pasir yang digunakan dalam proses penyangraian, yaitu pasir kali dan pasir gunung

Bahan-bahan yang digunakan dalam penelitian ini adalah, kerupuk udang merk Finna (KA 14\% ketebalan 2 mm, a $\theta$ $11 \mathrm{~mm}$ ), gas LPG $12 \mathrm{Kg}$., pasir kali yang diperoleh dari sungai Je'neberang Kecamatan Somba Opu

Kabupaten Gowa, dan pasir gunungdiperoleh dari Desa Bili-bili Kecamatan Parangloe Kabupaten Gowa.

Penelitian ini akan dilaksanakan di Laboratorium Pendidikan Teknologi Pertanian, Fakultas Teknik Universitas Negeri Makassar dan Lab Kimia Politeknik Negeri Ujung Pandang untuk analisis tekstur yang dilaksanakan pada jangka waktu penelitian mulai dari persiapan sampai dengan pengamatan, direncanakan membutuhkan waktu kurang lebih satu bulan, sejak diterbitkannya surat izin penelitian.

\section{HASIL DAN PEMBAHASAN}

\section{Profil Kadar Air Selama Penyangraian}

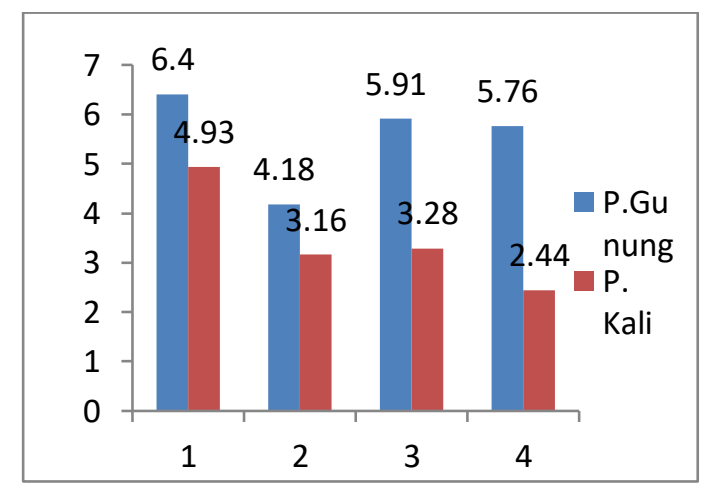

Gambar 1

Perubahan kadar air kerupuk selama proses penyangraian pada suhu $120^{\circ} \mathrm{C}$ dengan berbagai variasi lama penyangraian (detik) dimana pasir kali sebagai media penghantar panas. 


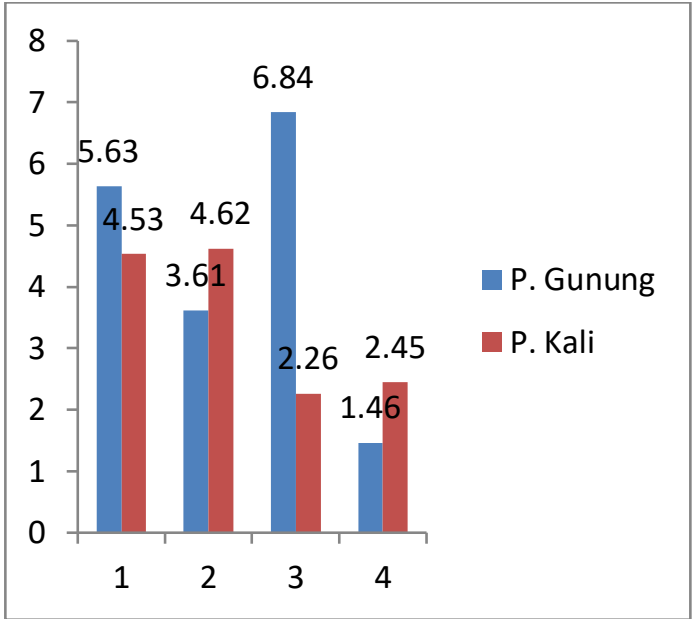

Gambar 2

Perubahan kadar air kerupuk selama proses penyangraian pada suhu $140^{\circ} \mathrm{C}$ dengan berbagai variasi lama penyangraian (detik) dimana pasir kali dan pasir gunung sebagai media penghantar panas.

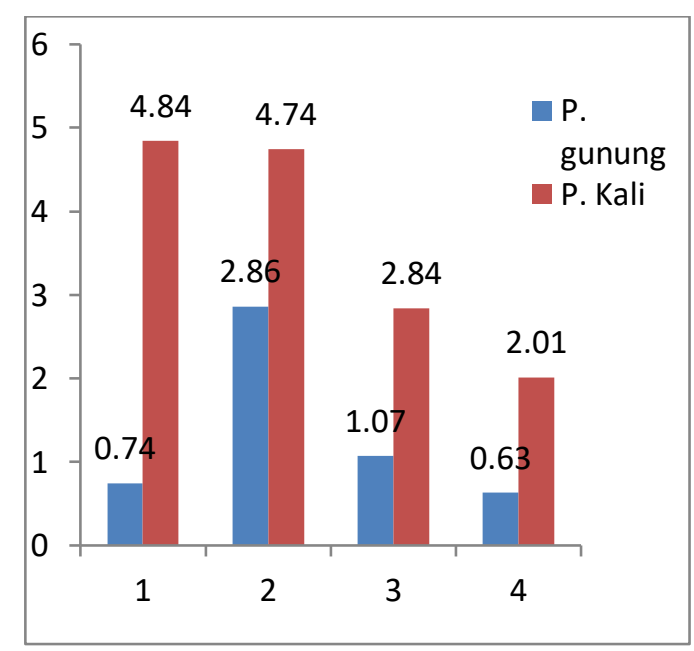

Gambar 3

Perubahan kadar air kerupuk selama proses penyangraian pada suhu $160^{\circ} \mathrm{C}$ dengan berbagai variasi lama penyangraian (detik) dimana pasir kali dan pasir gunung sebagai media penghantar panas.

\section{Profil Perubahan Tekstur Selama Penyangraian}

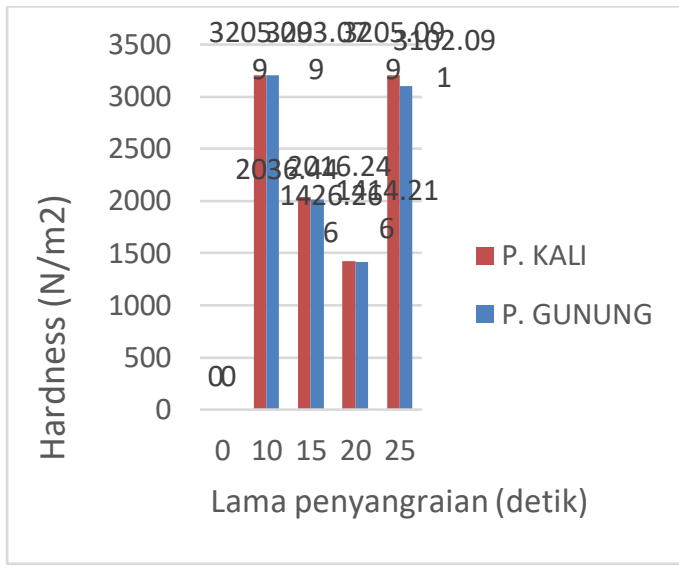

Gambar 4

Perubahan tekstur kerupuk selama proses penyangraian pada suhu $120^{\circ} \mathrm{C}$ dengan berbagai variasi lama penyangraian (detik) dimana pasir kali dan pasir gunung sebagai media penghantar panas

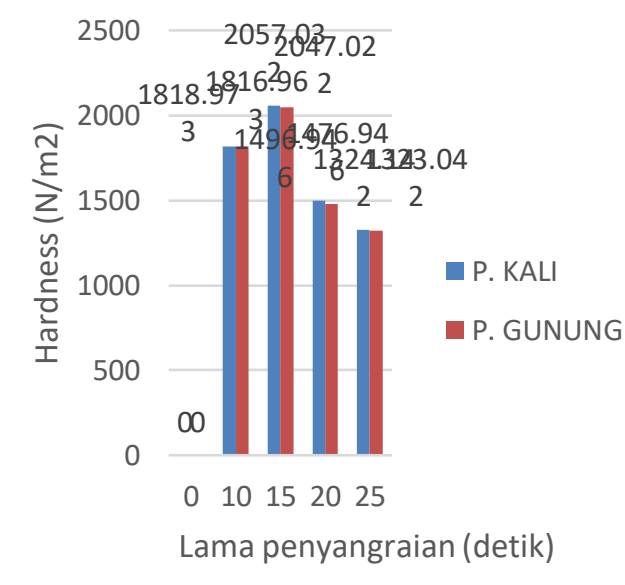

\section{Gambar 5}

Perubahan tekstur kerupuk selama proses penyangraian pada suhu $140^{\circ} \mathrm{C}$ dengan berbagai variasi lama penyangraian (detik) dimana pasir kali dan pasir gunung sebagai media penghantar panas 


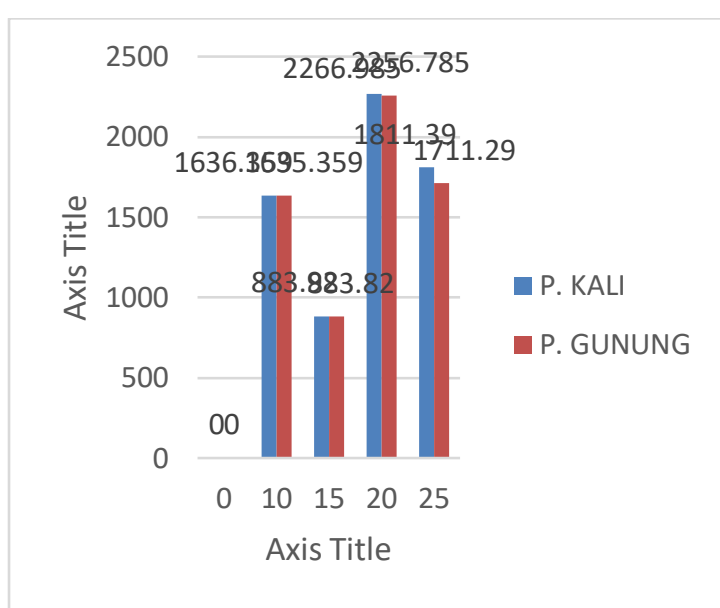

Gambar 6

Perubahan tekstur kerupuk selama proses penyangraian pada suhu $160^{\circ} \mathrm{C}$ dengan berbagai variasi lama penyangraian (detik) dimana pasir kali dan pasir gunung sebagai media penghantar panas

\section{Profil Kadar Air selama Proses Penyangraian}

Berdasarkan hasil dari uji kadar air kerupuk menunjukkan bahwa terjadi penurunan kadar air di setiap suhu dan lama penyangraian, penurunan kadar air tercepat terjadi pada penyangraian pada suhu $160^{\circ} \mathrm{C}$ dengan lama penyangraian 25 detik dengan kadar air 2,01\% pada penyangraian menggunakan pasir kali dan 0,63\% pada penyangraian menggunakan pasir gunung sebagai media panas. Penurunan kadar air yang paling rendah terjadi pada suhu $120^{\circ} \mathrm{C}$ dengan lama penyangraian 10 detik dengan kadar air 4,93\%. Sehingga dari hasil penelitian dapat diketahui bahwa semakin tinggi suhu dan lama penyangraian yang digunakan selama proses penyangraian, maka semakin rendah kadar air yang dihasilkan. Hal ini disebabkan karena semakin tinggi suhu dan waktu yang digunakan selama penyangraian, maka air dalam padatan/bahan akan semakin cepat mengalami proses penguapan, sehingga sangat berpengaruh terhadap kadar air dalam padatan.

Proses penguapan terjadi ketika bahan/kerupuk yang dimasukkan kedalam ruang penyangrai bersentuhan dengan media penyangrai/pasir, maka sedikit demi sedikit kadar air yang ada dipermukaan bahan akan terjadi penguapan dan semakin lama maka akan mempengaruhi karakteristik kerupuk menjadi lebih renyah. SNI kadar air kerupuk sebelum penggorengan maupun penyangraian maksimal $12 \%$, yang dapat diketahui pula bahwa kerupuk yang disangrai termasuk dalam SNI yang dimaksud atau tidak melewati batas standar yang ditetapkan. Selain itu, kadar air kerupuk sangat menentukan kondisi/hasil penyangraian yang diperoleh karena semakin tinggi kadar air dalam kerupuk maka kondisi kerupuk akan semakin keras. Sebaliknya, jika kadar air dalam kerupuk semakin rendah maka kondisi kerupuk akan semakin renyah. Hilangnya sebagian air bebas menyebabkan kekerasan padatan mengalami perubahan yang semula lunak akhirnya menjadi keras (Jamaluddin dkk, 2011).

\section{Profil Perubahan Tekstur Selama Penyangraian}

Selama proses penyangraian
kondisi tekstur kerupuk mengalami perubahan. Nilai hardness menunjukkan nilai daya patah yang digunakan dalam uji analisis tekstur untuk menentukan regangan ataupun tegangan pada kerupuk udang hingga mencapai kondisi fracture/patah. Menurut Jamaluddin dkk (2011) tegangan dan regangan didefenisikan sama dengan kekerasan dan kerenyahan.

Pengukuran tekstur pada kerupuk dilakukan dengan menggunakan uji tekanan (compression test), dengan menggunakan 
alat texture analyzer dimana probe akan menekan bagian tengah produk/kerupuk. Uji tekstur ini dilakukan untuk mengetahui tingkat kekerasan kerupuk, standar tekstur/nilai hardness kerupuk khususnya kerupuk udang saat ini belum ditentukan. Kerupuk yang akan dilakukan pengujian texture analyzer terdiri dari beberapa perlakuan yaitu jenis pasir suhu dan lama penyangraian. Jenis pasir yang digunakan yaitu pasir kali dan pasir gunung, suhu yang digunakan yaitu 120, 140 dan $160^{\circ} \mathrm{C}$ dengan masing-masing waktu 10, 15, 20 dan 25 detik.

Menurut Kartini (2006), Pada dasaranya tinggi rendahnya nilai hardness pada kerupuk disebabkan dari karakteristik bahan/kerupuk (ketebalan kerupuk, proses homogenisasi pencampuran bahan, kandungan bahan lainnya yang paling penting adalah pati dan kadar air yang dimiliki bahan). Proses perubahan tekstur kerupuk terjadi pada saat permukaan bahan dalam hal ini kerupuk menyentuh media sangrai/pasir menyebabkan penguapan air dalam bahan pangan yang menekan dari dalam bahan sehingga membentuk gelembung pada kerupuk untuk memaksa kadar air selanjutnya keluar dari dalam kerupuk dan pecahnya granula pati yang menyebabkan terjadinya proses pemekaran/pengembangan pada kerupuk, yang tentunya kondisi tekstur kerupuk yang dihasilkan akan sesuai dengan suhu dan lama penyangraian yang digunakan selama proses penyangraian. Hal ini didukung adanya pernyataan yang dikemukakan oleh Koswara (2009) mengatakan bahwa pada proses penggorengan akan terjadi penguapan air yang terikat dalam gel pati akibat peningkatan suhu dan dihasilkan tekanan uap yang mendesak gel pati sehingga terjadi pengembangan sekaligus terbentuk rongga-rongga udara pada kerupuk yang telah digoreng. Selain itu, ketebalan kerupuk mempengaruhi proses perambatan panas kedalam bahan sehingga berpengaruh pula pada tekstur bahan yang dihasilkan serta adanya proses pencampuran bahan yang kurang kalis menyebabkan kondisi pati dalam padatan kurang homogen dan hal ini juga mempengaruhi tekstur kerupuk yang dihasilkan.

\section{KESIMPULAN}

Berdasarkan hasil penelitian maka dapat disimpulkan bahwa pasir kali dan pasir gunung dapat mengubah tekstur kerupuk melalui penyangraian hal tersebut dikarenakan adanya perpindahan panas dari dinding pemanas pada pasir sehingga mempengaruhi kadar air dan kadar pati dalam kerupuk yang disangrai. Dalam proses penyangraian, Suhu mempengaruhi testur kerupuk yang dihasilkan, dimana suhu yang baik digunakan yaitu $140^{\circ} \mathrm{C}$ selama 20 detik untuk pasir kali dan $160^{\circ} \mathrm{C}$ selama 15 detik dengan menggunakan pasir gunung sebagai media penghantar panasnya.

\section{DAFTAR PUSTAKA.}

Irmayanti, Husain Syam dan Jamaluddin 2017. Perubahan Tekstur Kerupuk Berpati Akibat Suhu dan Lama Penyangraian. Jurnal Pendidikan Teknologi Pertanian, Vol. 3 : S165S174. Makassar: UNM

Jamaluddin, Budi Rahardjo, Pudji Hastuti\&Rochmadi.2011. Model Matematika Optimasi Untuk Perbaikan Proses Penggorengan Vakum Terhadap Tekstur Kerupuk 
Buah.Jurnal Teknik Industri.Vol 12 (1).:82-89

Kartini, Istiqamah. 2006. Pengaruh Lama pengeringan dan Variasi Perbandingan Formula Terhadap Karakteristik Kerupuk Tiras.Skripsi. Jurusan Teknologi Pangan. Universitas Pasundan : Bandung.

Koswara, Sutrisno. 2009. Pengolahan Aneka Kripik, (online), (website: Ebookpangan.com), diakses pada tanggal 30 Maret 2016.

Nirwana, Lina, Muh. Rais dan Jamaluddin. 2017. Konduktivitas Termal Pasir Kali sebagai Media Penghantar Panas pada Proses Penyangraian Kerupuk. Jurnal Pendidikan Teknologi Pertanian, Vol. 3 : S182S196. Makassar: UNM.

Siswantoro., Budi Raharjdo, Nursiqit Bintoro dan Pudji Hastuti. 2010. Model Matematik Perubahan Parameter Mutu Kerupuk selama Penggorengan dengan Pasir. Fakultas Pertanian. Universitas Jenederal Soedirman. Purwokerto.

Susanna, Jamaluddin dan Kadirman. 2017. Perpindahan Panas pada Makanan Berpati (Kerupuk Udang) selama Proses Penyangraian Menggunakan Pasir sebagai Media Penghantar Panas. Jurnal Pendidikan Teknologi Pertanian, Vol. 3 : S72-S79. Makassar: UNM. 